\title{
Private Voluntary Support to Public Universities in the United States: An Early History
}

Received (in revised form): January 3, 2003

\section{Samuel G. Cash}

Samuel G. Cash is Vice President for Institutional Advancement at Truett-McConnell College in Cleveland, Georgia. He completed his doctoral degree in higher education at the University of Georgia in December 2000. His research interests include philanthropy and finance in higher education. He is the cowinner of the 2002 John Grenzebach Research Award for outstanding doctoral dissertation in the area of educational fund raising, which is given each year by CASE. Dr. Cash has served various other nonprofit organizations and is a former staff member of PricewaterhouseCoopers. He is a certified public accountant.

\begin{abstract}
Recent trends in voluntary support of higher education indicate that public institutions are in greater competition for limited philanthropic resources with private institutions, at times blurring the distinction between public and private institutions, especially in the area of fund raising and institutional advancement. The question arises whether public institutions historically have relied on private voluntary support and how the pattern of support developed in response to the expanding requirements of these institutions over time. This study explores the early history of private voluntary support of public research universities in the United States from the time of the
\end{abstract}

\footnotetext{
Author's Contact Address:

Dr. Sam Cash

Vice President of Institutional Advancement

Truett-McConnell College

100 Alumni Drive

Cleveland, GA 30528, USA

Tel: +1 7068652134

Fax: +1 7062191744

Email:

scash@truett.edu
}

chartering of the first state university in 1785 through much of the antebellum period. This early history indicates that the first state universities, without a model for a type of institution free from sectarian control and reliant on the state for support, followed patterns of raising support established by the colonial colleges and relied on a combination of public and private support. These patterns provide the foundation for good practice in fund raising today.

\section{Keywords: \\ public universities, fund raising, voluntary support, bistory of higher education}

\section{Introduction}

When the University of Michigan became the first major public research university in the United States to mount a \$1 billion capital campaign in 1992, President James Duderstadt commented that "private support is absolutely critical." " Five years later Duderstadt used the phrase "privately financed public university" in a speech on the future of the nation's top public 
research universities; he noted "we used to be state-supported, then state-assisted, and now are state located." "In terms of voluntary support raised by private and public institutions today, there is little distinction between the two domains. For instance, half of the top 20 fund-raising colleges in 2000-1 were public institutions. ${ }^{3}$ Additionally, several major public universities have successfully followed the lead of Michigan by mounting campaigns in excess of $\$ 1$ billion.

The notion exists that in recent years, in reaction to fluctuating state support, public institutions turned to private dollars to fill in the gaps. In search of a margin of excellence and increasing autonomy, the major public research universities committed more resources than ever to the area of institutional development. In perhaps what is thought historically to be the domain of private institutions, public universities now excel in raising private voluntary support; however, the early history of voluntary support to the first state universities suggests this blur between the public and private has existed for some time. This paper traces the early development of a pattern for raising private voluntary support at the first state institutions, which today have grown into the major public research universities of the United States.

\section{Early Influences}

For the states chartering their own universities soon after the ratification of the Constitution and prior to the Civil War, the issue of funding would be preeminent. Private support played a prominent role in keeping these institutions solvent in much the same way as the colonial colleges. However, the nature and pattern of private voluntary support had to adjust to many influences, including ideas about funding formed in the colonial period, an unclear federal interest in higher education, inconsistent economic patterns, sectarian rivalries, and an emerging public-private concept of higher education in the United States.

First, state-supported higher education had no better precedent to follow for ideas of financial support than the colonial colleges. In terms of support, colonial colleges such as Harvard, Yale, Princeton, and others, were a curious private and government hybrid. Support was raised from both private and government sources in varying amounts, depending on the institution and the belief of local colonial officials as to whether these institutions would supply the civic leaders their new governments would require. A prevalent attitude toward higher education was that if the social purpose of inculcating civic virtue and promoting social sponsorship among the privileged was being accomplished, higher education was worth supporting. ${ }^{4}$ As the new nation emerged after the Revolution, national purposes defined by republicanism replaced social purposes once readily accepted for colleges:

Social purpose might also be defined as national purpose. A commitment to the republic became a guiding obligation of the American college. The American people were conducting an experiment in free government of a nature and scope that the world had not yet known. The American college intended to serve that mission. ${ }^{5}$

As the states attempted to find institutional expression for these purposes, questions were to emerge regarding 
responsibility for funding among citizens of the state and within the statehouse as well.

Another factor affecting the private support of the early state universities was an apparent misconception regarding the federal interest in publicly supported higher education. Upon the adoption of the United States Constitution the new Republic nurtured an ideology about the promotion of the common good and the control of one's economic destiny. ${ }^{6}$ The means to promote and nurture this ideology would include education, especially higher education. It is interesting to note, however, that the Constitution makes no reference to responsibility for education: responsibility for education was abdicated to the states. ${ }^{7}$ Some of the constitutional framers, including Thomas Jefferson, suggested the federal government assume some responsibility for a type of public education free from sectarian interests. Further, President George Washington advocated a national university and left shares of stock in his will to establish such a university. ${ }^{8}$ Evidence of interest in public education on the federal level emerged with the approval of the Land Ordinance of 1785 that reserved one square mile of federal lands in each township of the newer states of the West for supporting "seminaries of learning." These original federal land grants feebly supported the initial endowments for state universities. Without clear guidance for the states, the responsibility for the promotion of higher education would remain loosely in the hands of private citizens and religious groups.'

At the time of the rise of the first state universities the economies of the United States and the individual states were not developed enough to allow a thorough constant mode of philanthropic support to higher education. For the years between the Revolution and up to 1820 , per capita incomes rose more slowly than in previous years; wage levels barely kept up with rises in the cost of living. ${ }^{10}$ This was a period during which the economies of the various regions and locales of the country were not fully integrated into a solid national economy. ${ }^{11}$ Despite the changing economy's effect on levels of support for an emerging system of higher education, citizens would band together in support of colleges for their communities, regardless of whether the institution was state or sectarian. A booster spirit within townships and cities emerging in the newer western states provided an impetus for individuals to support an institution which would bear the mark of civilization to an outside observer. ${ }^{12}$

The presence of sectarian conflicts during the founding of state universities affected private voluntary support. The rise of numerous private colleges during the antebellum period has been attributed to the sectarianism of the times. Churchrelated colleges drew support away from state universities while creating antagonism toward them. This antagonism fed a suspicion that state universities were created to educate an elite much like colonial institutions. Additionally, leaders of the evangelistic Protestant denominations regarded the state universities "as godless or friendly to some other denomination." 13 The result was difficulty in raising regular tax support from state legislatures, which made little distinction between all colleges chartered within their states.

This lack of distinction points to a major issue facing higher education at the 
time-there was not a true dividing point between what would later be known as public and private higher education. Without the distinction, all institutions would compete equally for financial support from individuals and the state. The public-private question was addressed in the opinion handed down by the Supreme Court in 1819 that clarified the private nature of Dartmouth College. In terms of governance, all institutions of higher education sought an approved charter from the state legislature, and the Dartmouth College case perhaps answered the question of who governed the college. The trustees brought a suit against the state legislature for amending the charter of 1769 to make Dartmouth public. ${ }^{14}$ Upon closer inspection of the Dartmouth case, the Supreme Court justices based their decision on the private nature of support, but the decision offered little insight for a state institution relying on private support. Private gifts, according to Justice John Marshall, imply a contractual obligation between the college and the donor. If the contractual nature implied by a private gift helps determine the type of institution, then a state university that relied on private support had a greater obligation to its supporters than to the state which bore its existence through an approved charter. Justice Marshall questioned whether the will of the state could be substituted for the will of the donors to a college; further, if the state managed and applied the funds to a use not according to the will of the donors, then the contract was subverted and the institution did not act in good faith. ${ }^{15}$

Such reasoning might have labeled American colleges and universities not as public or private, but as philanthropic. In other words, even though state universities and private colleges relied on both private and government support in some combination, there really could be no distinction, especially in terms of support, between the two types of institutions.

Philanthropic gifts to the state universities during the period after the Revolution through the Civil War would reflect these basic themes. The methods for raising private funds by the colonial colleges proved to be popular throughout this period. Purposes for giving shifted from a purely religious motive and a concern for civic development to a mixture of motives peculiar to the conception of public higher education. These purposes may be seen in the patterns of voluntary support that developed throughout this period.

\section{Raising Private Support: Early Trends}

The first of the methods of raising voluntary support that seemed to enjoy a successful tenure through this period was the subscription. During the colonial period, the appeal for subscriptions from individuals was a common method of raising private support, one that enjoyed a great deal of success due to its appeal to local pride or some special interest. The idea of "giving with others" developed into an important feature of American philanthropy during the years prior to the Civil War. ${ }^{17}$ A certain pride of association could have contributed to the success of the subscription. This pride of association is perhaps evident in what has been called the "booster spirit" of antebellum United States. Cities developing in the new nation wanted to boast of having all the hallmarks of a great metropolis, including an institution of higher learning. More than ever before, citizens turned their 
concern from the former reasons for supporting colleges to the new concerns of community development and economic advancement. ${ }^{18}$ These concerns, as well as the personal appeal, fueled the successful subscription drives and led ultimately to the fund-raising campaign. Time and time again, institutional leaders would turn to their communities for support as the purposes and curricula of higher education expanded.

Many of the state universities sought their initial financial support through voluntary gifts raised by subscription. Some of the earliest indications that subscriptions played an important role in the start-up phase of state universities occurred at the University of Vermont and the University of North Carolina. During 1791, several Vermont town boosters raised subscriptions from citizens in an effort to attract the state university to their "civilized" community. Perhaps strengthened by Ira Allen's large gift of $£ 4,000$, the town of Burlington raised the most support for the university. ${ }^{19}$

Circumstances were similar in North Carolina. After obtaining a charter for the University in 1789 , leaders from a site committee solicited contributions from friends in their respective counties in efforts to compete for the state university. Trustee James Hogg and his Orange County friends successfully raised nearly $£ 798$ and donations of land approximating 1,386 acres for locating the University at New Hope Chapel Hill. ${ }^{20}$ In Tennessee, Blount College, the nonsectarian predecessor to the state university, received the donation of the town square of Knoxville in 1795, from trustee and founder of Knoxville James White, for the purpose of erecting a twostory frame building as the first building of the college. Subscriptions supported this initial construction. ${ }^{21}$

The underfinanced, delayed opening of the University of Georgia appeared to be the reason for the circulation of subscription lists and appeals for aid in the state's newspapers in $1798 .^{22}$ The fashion of publicizing subscription lists in newspapers apparently was not infrequent. The Detroit Gazette of September 19, 1817 noted subscriptions of $\$ 1,060$ for the University of Michigan; subscription lists perhaps encouraged a pride of association which resulted in other donations and pledges exceeding \$3,000 only a month later. ${ }^{23}$ In Kentucky, the fledgling Bacon College would relocate according to the intent of trustees to the location where the largest subscription could be garnered. In 1839 , this institution, which was to become the University of Kentucky, raised enough pledges from Mercer County through the fund-raising efforts of lawyer James Taylor to relocate there. ${ }^{24}$ Almost a decade later, another subscription campaign raised nearly $\$ 11,000$ for Kentucky's university. ${ }^{25}$ As a testimony to the commitment of small communities to help underwrite a nonsectarian state university, over 900 individuals subscribed money or land to the drive to attract the University of Missouri to Columbia and Boone County in $1839 .^{26}$ Subscriptions for Missouri's university totaled $\$ 82,389$ in cash and $\$ 35,540$ in land. ${ }^{27}$ This fund-raising feat is more remarkable because it happened at a time near the national banking crisis referred to as the Panic of $1837 .^{28}$

Similar to the role of the presidents and trustees during the colonial days, institutional leaders at the newly formed state universities played a significant role to insure the financial stability of the institutions. The personal search for gifts 
by trustees, presidents, and friends of the state institutions became an important component of the developing pattern of fund-raising methods. Such searches typically began with the recognition of a specific need and followed through with a one-on-one invitation to contribute to this need. Trustees exhibited an understanding of their fiscal responsibility by mobilizing citizens to contribute to their state universities. In North Carolina, some of the nearly 70 men who served on the Board of Trustees were generous with their time devoted to acts of raising support. ${ }^{29}$ John Haywood of Raleigh successfully raised funds in the early years of the university while serving as state treasurer from 1787 through $1827 .^{30} \mathrm{~A}$ land surveyor and public office holder, William Polk of Mecklenburg County was a leading fund raiser for the university from 1790 through 1834 while serving as a trustee. ${ }^{31}$ During times of financial difficulty, trustees exhibited their concern for their institution in Vermont. The years leading up to the 1820 s were difficult due to the lack of progress toward obtaining indemnification from the United States government for damages by troops to lands in Vermont, money which would directly support the university. ${ }^{32}$ After the resignation of the university president in 1821 , trustees asked the citizens of Burlington for financial support. Again in 1824, the trustees would turn to Burlington for funds to reconstruct the main college building, which had burned to the ground. ${ }^{33}$ The trustees and the citizens of Burlington developed an alliance and a group of citizens rallied support of $\$ 8,362$ for a new building. ${ }^{34}$

From accounts of the early state universities it is clear that the institutions' presidents sensed their leading role in raising private voluntary support. Early presidents at both the University of North Carolina and Georgia illustrated their earnest involvement. North Carolina's first president, Joseph Caldwell, traveled the state in his buggy to meet with citizens and seek their financial support. Caldwell probably delivered emotional appeals for financing to stem the declining condition of the institution. At one meeting the response was a spontaneous subscription to improve the condition of the institution, particularly from the younger persons present at the meeting. ${ }^{35}$ Using these tried and true methods, Caldwell raised $\$ 12,000$ by 1812 , enabling the completion of the construction of the main college building by $1814 .{ }^{36}$ The University of Georgia's fourth president, Presbyterian minister Robert Finley, took over the leadership at a time of financial exigency in 1816. Possibly due to the financial condition of the institution, Finley promptly set out "on a preaching/ begging tour of surrounding counties." 37 In contrast to the success of Caldwell in North Carolina, Finley could not account for raising any funds from his tour. Sadly, President Finley died in 1817 of typhus contracted during a recruiting trip through the state. ${ }^{38}$ Although North Carolina and Georgia provide contrasting illustrations of success in presidential fund raising, the president's involvement in this task would not relent in the ensuing years and would focus on the relationship between the institution, its state, and its sponsoring society.

The personal search for gifts, whether by the president or trustees, helped sustain antebellum state universities lacking state funding. In some cases, a third party or group of individuals mounted a personal 
campaign for private contributions to support the state institutions. Despite the common sectarian rivalries at state institutions, ministers at times sought private gifts for the state universities. At the University of Georgia, a Methodist minister, Hope Hull, was appointed by the Board of Trustees to serve as chairman of a committee to direct the affairs of the institution between sessions of the board. In 1807, Hull sought and won approval for the construction of a chapel on the campus. ${ }^{39}$ Through personal pleas, Hull raised near $\$ 250$ and added $\$ 689$ of his own funds for the chapel, which was completed in 1808 .

Another example of the support of ministers at a state institution is available in the initial phase of the University of Vermont. Ira Allen enlisted the support of Reverend Samuel Williams in promoting the initial need for a state university and then raising the financial support to operate it. Reverend Williams was a Puritan and a Harvard graduate with a scholarly background. He had a prominent New England ancestry and an industrious attitude toward starting a college in Vermont. Through frequent correspondence with "persons of note" and his scholarly colleagues, Williams procured gifts both locally and from abroad, including books from London, Paris, and other parts of Europe as well as subscriptions from England and Canada. ${ }^{41}$ At other times in the early years, Vermont's university turned to the clergy for help in raising private funds. In one situation a Congregational pastor, Reverend Daniel Haskel, was appointed agent to solicit financial support subsequent to a five-year subscription drive in 1817. Haskel was later named president of the institution in $1821 .^{42}$
Another development in the use of agents to raise funds for the state institutions involved students who banded together to raise funds for what they perceived to be the needs of the institution. Although these needs may have appeared self-serving, the benefit to the institution over time would prove immeasurable-here was the foundation for developing alumni associations and for promoting the successful fund-raising technique of giving with others. For example, students at the University of Virginia raised private funds for employing a chaplain in 1832. Sectarian rivalries may have contributed to this movement; however, it is to the credit of the small student body to have recognized their need and organized a fund drive to raise private support at an institution funded generously by the state. The students started the drive with approval of the faculty and visitors and within two years raised the necessary funds for the position. Curiously, the chaplaincy was considered to have no official connection with the institution due to the support coming solely from private funds rather than a combination of state and private funds. ${ }^{43}$

Another convenient avenue for student fund raising was the literary society.

Fostered by the lively political interests of the times, the literary societies at the state universities identified their need for physical space as their membership and library holdings grew. The Philanthropic Society and the Dialectic Society at the University of North Carolina were almost forced into raising private funds for their own buildings. Each group had their own overcrowded room in South Building, the main campus building. In 1832 the societies endeavored to raise funds for 
their own buildings. The simultaneous drives fueled the rivalry of the two societies. As one Philanthropic Society alumnus said, "Take care that you do not fall in the rear. I am willing unconditionally to subscribe ten dollars, but would be willing to double that sum rather than you should fail for want of funds." ${ }^{44}$ Despite the rivalry and the overcrowded conditions of South Building, the fund-raising campaigns failed. ${ }^{45}$

In contrast to the competing literary societies at the University of North Carolina, the Demosthenians and the Phi Kappans at the University of Georgia experienced success in raising private funds for their own campus buildings. Similar to the situation at North Carolina, the lack of adequate meeting space and the rivalry between the Demosthenians and the Phi Kappans compelled the Phi Kappans to initiate a subscription campaign among the society's alumni in 1831. ${ }^{46}$ The Phi Kappans successfully raised private gifts of near $\$ 3,500$, which was enough to finance the construction of their building. ${ }^{47}$ After the building was completed in 1836, additional costs forced the Phi Kappans to raise additional funds from prominent alumni Howell Cobb, John Milledge, and J.P. Charles Whitehead, after a failed attempt to solicit financial support from the Georgia legislature. By 1838 , the hall was completely paid for at nearly $\$ 5,000$. $^{48}$

Although subscription campaigns caught the excitement of a community and a student body, other avenues for raising private support emerged slowly as the early state universities developed. Noncash gifts, such as gifts of books and land, were not as common as the gifts that were raised through the ubiquitous subscription campaigns. However, these types of gifts provided important resources at a time when the physical needs of the institutions were great. An account of the conditions at Indiana University in the mid-1830s illustrates the conditions that prompted certain gifts:

Reflecting the lowly estate in which Indiana University was beginning operation, [President] Andrew Wylie informed the trustees in a lengthy communication that much better provisions had to be made for the teaching of natural philosophy and chemistry. Storage cases had to be constructed to house instruments and chemicals. The college building was unsafe for use of inflammable materials; water was not available to conduct experiments or to quench accidental fires. Heating stoves were no good as sources of heat; besides they would be lethal in conducting proper laboratory procedures. ${ }^{49}$

Despite these dismal conditions, a penurious Board of Trustees, and little support from state coffers, President Wylie found support from individuals, including a generous gift of books from the personal library of William Maclure. ${ }^{50}$ Personal libraries provided resources for other institutions as well. The University of North Carolina benefited from the gift of 32 books from a citizen of Orange County in 1796, prompting a resolution from the trustees, which listed the individual titles without placing a specific value on them:

In the Board of Trustees, July 13th, 1796. Richard Bennehan Esquire, of the County of Orange in the said state, 
having this day presented to the Trustees for the use of the students of the University of North Carolina Thirty two volumes of well bound and well chosen Books; Resolved that the Trustees do thankfully accept them, and that the President of the Board be requested to inform Mr. Bennehan that they have a due sense of the worth of such his valuable donation and that they will cause mention thereof to be made in the Book kept for that purpose. ${ }^{51}$

Apparently an exceedingly famous work by a famous man given to the University of Georgia in 1808 was considered significant enough to prompt an even greater acknowledgement than in North Carolina. Joel Barlow, a close friend and fellow Yale graduate of Georgia President Josiah Meigs, asked Meigs to review his personal Columbiad. Barlow sent the university a handsome, leather-bound copy in 1808 . In return, the university presented Barlow with the LL.D. degree. ${ }^{52}$ The University of Georgia received numerous gifts of books throughout the early 1800s, placing its number of library holdings higher than most institutions in the South or West. ${ }^{53}$ The growth of religious denominations provided many gifts of theological books. Shelves were filled to the point that the Board of Trustees called for these gifts to cease in 1834. Soon after, Georgia governor George Gilmer gave his collection of bound newspapers to the university and later willed his private library to the institution. Additionally, the British government gave 90 volumes of the acts and debates of Parliament to Georgia's growing library. ${ }^{54}$

Another tangible asset that would benefit many a newly formed state university was land. A committee formed by the University of Georgia's first president, Abraham Baldwin, was charged with locating a suitable parcel of land for the institution several years after its charter was obtained. The committee selected an area on the Oconee River, at which time committee member John Milledge purchased the land and gave it to the university. ${ }^{55}$ The tract of land totaled 633 acres and the Board of Trustees set aside 37 acres for the college grounds and parceled the remaining land into town and farm lots. 56

Large land donations helped sway the decision to locate the University of North Carolina in Orange County. Gifts of land totaled 1,386 acres from 12 individual donors. The individual tracts, the largest at 221 acres and the smallest at 5 acres, were contiguous and near a major road intersection. Additionally the land was on the summit of a ridge described as a beautiful hilltop forest. ${ }^{57}$ Although the land was donated, the largest tract, owned by James Craig, was actually given in exchange for the small sum of five shillings according to the deed. ${ }^{58}$

\section{Conclusion}

By the outbreak of the Civil War an inconsistent pattern of support for the state universities still prevailed. Most of the state universities continued their struggle to obtain needed support from their states. Exceptions existed, however, in Virginia and South Carolina, where regular state appropriations were a significant part of the support of their state university. Private giving to the state universities during the years preceding the Civil War revealed issues peculiar to the funding of higher education. Institutional leaders attempted an understanding of the 
motives for giving. However, they were never able to focus on developing regular sources of private support, probably due to regular conflicts with their states over funding. In terms of support, the early state institutions did little more than resemble the sectarian institutions of the day and, perhaps to a greater extent, the colonial colleges. As these institutions progressed, however, private support did not abate through periods of unstable state support. Private support through subscriptions and in-kind gifts stabilized an otherwise precarious fiscal status for these institutions as the forerunners of alumni associations and "town-and-gown" relations gave state institutions a firm foundation in the realm of private fund raising.

\section{References}

1. Julie L. Nicklin (1992), “U. of Michigan’s \$1-billion capital campaign is biggest ever for a public university," The Chronicle of Higher Education, September 30, A27.

2. David Breneman (1997), “The 'privatization' of public universities: Mistake or model?" The Chronicle of Higher Education, March 7, p.B2.

3. John Pulley (2002), "Private giving to colleges surpassed expectations in 2000-1," The Chronicle of Higher Education, April 5, p.A24.

4. Phyllis Vine (1976), "The social function of eighteenth-century higher education," History of Education Quarterly, 16, Winter, p. 409.

5. Frederick Rudolph (1962), The American College and University: A History, Alfred Knopf, New York, quote from reprint with an introductory essay and supplemental bibliography by John R. Thelin (1990), The University of Georgia Press, Athens, p. 61.

6. Cathy Matson (1996), "The Revolution, the Constitution, and the new nation," in Stanley L. Engerman and Robert E. Gallman (Eds.), The Cambridge Economic History of the United States, vol. 1, Cambridge University Press, Cambridge, UK, p. 363.

7. Homer D. Babbidge, Jr. and Robert M. Rosenzweig, The Federal Interest in Higher Education, McGraw-Hill, New York, p. 1.

8. David Madsen (1996), The National University: Enduring Dream of the USA, Wayne State University Press, Detroit, MI, pp. 32-4.
9. Ibid., p. 3 .

10. Matson (1996), "The Revolution, the Constitution, and the new nation," op. cit, p. 400.

11. Ibid., p. 401.

12. Daniel J. Boorstin (1965), The Americans: The National Experience, Random House, New York, p. 152.

13. Rudolph (1962), The American College and University, op. cit, p. 280.

14. Jurgen Herbst (1982), From Crisis to Crisis: American College Government, 1636-1819, Harvard University Press, Cambridge, MA, p. 242.

15. John Marshall, opinion from "The Trustees of Dartmouth College vs. Woodward," in Ross M. Robertson and James L. Pate (Eds.), Readings in United States Economic and Business History, Houghton Mifflin Company, Boston, pp. 245-7.

16. John S. Whitehead and Jurgen Herbst (1997), "How to think about the Dartmouth College case," in Lester G. Goodchild and Harold S. Wechsler (Eds.), The History of Higher Education, 2nd edn., Simon \& Schuster Custom Publishing, Needham Heights, MA, pp.163, 166.

17. Robert H. Bremner (1988), American Philanthropy, 2nd edn. The University of Chicago Press, Chicago, p. 44.

18. Boorstin (1965), The Americans, op. cit, p. 152.

19. John S. Whitehead (1973), The Separation of College and State: Columbia, Dartmouth, Harvard, and Yale, 1776-1876, Yale University Press, New Haven, CT, p. 48.

20. William D. Snyder (1992), Light on the Hill: A History of the University of North Carolina at Chapel Hill, The University of North Carolina Press, Chapel Hill, pp. 14-15.

21. James Riley Montgomery, Stanley J. Folmsbee, and Lee Seifert Greene (1984), To Foster Knowledge: $A$ History of the University of Tennessee, 1794-1970, The University of Tennessee Press, Knoxville, p. 10.

22. Merton E. Coulter (1973), College Life in the Old South as Seen at the University of Georgia, The University of Georgia Press, Athens, p.11.

23. Howard H. Peckham (1994), The Making of The University of Michigan, 1817-1992, Bentley Historical Library, University of Michigan, Ann Arbor, pp. 78.

24. James F. Hopkins (1951), The University of Kentucky: Origins and Early Years, University of Kentucky Press, Lexington, p. 44.

25. Ibid., p. 45.

26. Jonas Viles (1939), The University of Missouri: A Centennial History, University of Missouri, Columbia, pp. 20-1.

27. Ibid., p. 19.

28. Ibid., pp. 20-1. 
29. William S. Powell (1992), The First State University: A Pictorial History of the University of North Carolina, 3rd edn., The University of North Carolina Press, Chapel Hill, p. 9.

30. Ibid.

31. Ibid

32. Julian Lindsay (1954), Tradition Looks Forward-The University of Vermont: A History, 1791-1904, The University of Vermont and State Agricultural College, Burlington, p. 118.

33. Ibid., p. 122.

34. Ibid., p. 123.

35. John V. Allcott (1986), The Campus at Chapel Hill: Two Hundred Years of Architecture, The Chapel Hill Historical Society, Chapel Hill, p. 19.

36. Ibid.

37. Coulter (1973), College Life in the Old South, op. cit., p. 31.

38. Thomas G. Dyer (1985), The University of Georgia: A Bicentennial History, 1785-1985, The University of Georgia Press, Athens, p. 23.

39. Ibid., p. 20.

40. Coulter (1973), College Life in the Old South, op. cit., p. 47.

41. Lindsay (1954), Tradition Looks Forward, pp. 16-17.

42. Ibid., pp. 118,121

43. Virginius Dabney (1981), Mr. Jefferson's University: $A$ History, University Press of Virginia, Charlottesville, pp. 12-13
44. Allcott (1986), The Campus at Chapel Hill, op. cit., p. 32.

45. Ibid.

46. Coulter (1973), College Life in the Old South, op. cit., p. 104.

47. Joel Thomas Bowen, Jr. (1990), "Room to grow: A historical analysis of the physical growth at the University of Georgia, 1785 to 1990,” Ed.D. dissertation, University of Georgia, p. 46.

48. Coulter (1973), College Life in the Old South, op. cit., p. 105.

49.

Thomas D. Clark (1970), Indiana University: Midwestern Pioneer, Vol. 1: The Early Years, Indiana University Press, Bloomington, p. 54.

50. Ibid., p. 57.

51. R. D. W. Connor (1953), A Documentary History of the University of North Carolina, 1776-1799, vol. II, The University of North Carolina Press, Chapel Hill, pp. 37-8.

52. Coulter (1973), College Life in the Old South, op. cit., p. 17.

53. Ibid.

54. Ibid., p. 40.

55. Dyer (1985), The University of Georgia, op. cit., p. 12.

56. Bowen (1990), "Room to grow," op. cit., p. 19.

57. Snyder (1992), Light on the Hill, op. cit., pp. 14-15.

58. Connor (1953), A Documentary History, vol. II, op. cit., pp. 76-7.

\section{Practitioner's Perspective}

As the chief advancement officer at an institution that serves as both the major land grant and state university in Arkansas, and as a consultant at many other public universities, I find high practical value in Sam Cash's research. There have been some seminal works on the history of higher education fund raising, but they have focused mainly on private colleges and universities and overlooked their public counterparts. Sam Cash addresses that oversight in an article based on his award-winning dissertation that demonstrates the extent to which private gift support has been an intrinsic part of public higher education since the chartering of the first state university in 1785.

The utility of Dr. Cash's research can hardly be overestimated. It becomes an important piece of historical revisionism that allows development officers at public universities to counter several misperceptions still held by some of our benefactors and prospects. Some of those misperceptions are as follows: (1) that only over the last 20 years have public universities been fund raising with any sort of proficiency; (2) that public universities have had no business, certainly no historical precedents, in "trespassing" on what has been deemed to be the private 
preserve of private institutions of higher learning-educational fund-raising; and (3) that public universities will never raise private dollars as effectively as private institutions. Dr. Cash musters ample evidence to discount those three fallacies. Indeed, he shows that public colleges and universities have been as dependent upon private gift support as the privates and nearly as proficient in raising them.

Beyond countering misconceptions, Dr. Cash's research holds particular implications for fund raisers at public universities in the South, in the area where I work. With the exception of the University of Vermont, the state university movement took root first in the American South. Although there were some fledgling state universities in the upper Midwest, not until the land grant colleges came into being after the Civil War were the seeds of strong public universities planted in the Northeast, Midwest, and West. Dr. Cash explores the early precedents of fund raising at the nascent state universities in North Carolina, Georgia, Tennessee, Kentucky, and Missouri and illustrates the essential role private gifts played in allowing these institutions to stabilize and grow. These are historical object lessons that development officers at public institutions can use time and again to make key points about the role of philanthropy in shaping great public universities.

If I may add my own exclamation point to Dr. Cash's thesis: as I write this (winter 2003), the Chronicle of Higher Education has just published its occasional updating on the 21 American universities that are currently in campaigns with goals of at least $\$ 1$ billion. Of those 21 universities, a majority-12 or 57 percentare public universities. Without question, public universities have learned their fund-raising lessons well and, thanks to Dr. Cash's splendid article, it becomes easier to understand why. 